\title{
The idea of the African university in the twenty first century: Some reflections on Afrocentrism and Afroscepticism
}

\author{
K. Horsthemke \\ Wits School of Education \\ University of the Witwatersrand \\ Johannesburg, South Africa \\ horsthemkek@educ.wits.ac.za
}

\begin{abstract}
The idea of 'the African university' is usually accompanied by an emphasis on Africanisation of education, and of knowledge, on changing the demographic profile of student, staff and administrative bodies, educational syllabi and curricula, and the criteria for research activity and for throughput. The idea of 'Africanising' universities is frequently couched within a conception that is explicitly 'Afrocentric'. On the other end of the spectrum, doubts about the idea of 'Africanising' universities frequently give rise to a kind of 'Afroscepticism'. The net result has been a dialogical impasse between these two positions, each accusing the other of racial hegemonism. The valuable insights that characterise these different views need to be taken into account in order to arrive at a balanced perspective regarding African higher education in the twenty first century. Ultimately, however, neither Afrocentrism nor Afroscepticism provide a compelling framework for transformation of tertiary education. My own position, while rather critical of the Afrocentric project and of the idea of 'the' African university, stops short of a thoroughgoing scepticism. It is informed both by what might be called 'Afrorealism' and the cautious hope that Africa and her universities will flourish in the twenty first century, whether in spite or because of globalisation.
\end{abstract}

\section{INTRODUCTION: THE IDEA OF 'THE AFRICAN UNIVERSITY'}

The idea of 'the African university' is usually accompanied by an emphasis on Africanisation of higher education, on 'changing the composition of student, staff and administrative bodies', changing educational syllabi/content as well as curricula - that is, 'the whole way that teaching and learning is organised' -, and changing 'the criteria that determine what is excellent research' (Moulder 1995, 7). James Moulder explains,

The excellence of a research programme lies in the way in which a problem is tackled rather than in the problem itself. Someone who pleads for Africanising our research programmes is not pleading for the lowering of standards, but simply asking that South Africans focus on problems that have their roots and significance in Africa. (Moulder 1995, 7).

Coupled with the Africanisation of higher education and research programmes is a focus on the 'Africanisation of knowledge' (Seepe 2000). 
Barney Pityana elaborates on the demands that higher education is being subjected to in terms of a series of transformations: 'transformation as representativity reflecting the demographic profile of the country at all levels of the life of the institution'; 'transformation as sound financial management within diminishing resources; ... transformation as strategic positioning and occupying a place of esteem among one's peers and attracting large financial resources from the private sector' and 'transformation as throughput rates and research profile', transformations within which 'we must find and be centred by the core values and philosophy of the university, the very one that must ultimately serve all the other expectations and demands' (Pityana 2004, 4).

The notion of 'Africanisation' can have either positive or negative connotations, depending on who is employing the term. Certain differences in emphasis and meaning attached to the term notwithstanding, Moulder, Pityana, Malegapuru Makgoba, Mogobe Ramose and Sipho Seepe's use of 'Africanisation' is essentially affirmative (Moulder 1995, 7, 8; Pityana 2004, 1, 4; Makgoba 1997 passim; Ramose 1998; Seepe 2000 passim). However, there is also considerable potential for derogation in the term. The emphasis on 'representativity' and 'throughput rates' may be of serious concern to someone worried about reverse discrimination and the lowering of standards and who anticipates a 'dumbing down' of Africa: 'The new racism ... speaks in codes, subtexts, coded hints. "Africanisation", for example, means: They are ruining our country.' (Grill 2003, 320).

These different connotations indicate two diametrically opposed orientations. In contrast to both of these, the position I defend here, which could be called 'Afrorealism', detects in the use of the term 'Africanisation' a plea for cultural and contextual sensitivity, albeit one that is somewhat misguided in the choice of a conceptual framework.

\section{AFROCENTRISM}

The idea of 'Africanising' universities is frequently couched within a conception and language that are explicitly 'Afrocentric'. Afrocentrism does not simply mean teaching students about Africa, its history, cultures, philosophy and values. It means 'placing Africa at the centre', historically, culturally, philosophically and morally (Schiele 1994, 152; Ani 1994). It encompasses the view that Africa is the cradle of humankind and the locus of the first great civilizations from which all others derive (Asante 1980, 45; Asante 1987, 170; Van Sertima 1999; Seepe 2000). It teaches that Africa is the birthplace of technology, metallurgy, astronomy, mathematics, agricultural science and medicine (Asante 1980, 45; Van Sertima 1999; Seepe 2000), and that African values are superior to European values. With regard to the latter, theorists like Molefi Kete Asante claim at times that African 
values are superior for Africans, just as Europeans deem European values to be superior (Asante 1980, 54; Asante 1987, 62, 180), and at other times that African values are plainly superior (Asante 1980, 9, 10; Asante 1987, 170).

Makgoba's book Mokoko, part autobiography part monograph, offers a sustained defence of both Afrocentrism and the Africanisation of higher education. At its heart is an emphasis on relevance: 'The contextualisation of higher education is fast becoming the challenge of universities' (Makgoba 1997, xxi). This central concern pervades Makgoba's thoughts on transformation, knowledge production, Africanisation of higher education, Afrocentric education, as well as knowledge production, diversity, internationalisation and global economic competition.

\section{Transformation}

According to Makgoba, the 'broad questions, challenges, battles or problems' facing the university 'during this period of rapid and contested change are: transformation, access, affirmative action, cultural and curricular change' (Makgoba 1997, 95):

Transformation is underpinned by three closely related factors: race, gender and culture. Once these three are tackled appropriately, they translate into legitimacy, transparency, stability, curricular change and peace on campus. (Makgoba 1997, 96).

The 'most critical and essential parameters in the process' of transformation of tertiary institutions are 'i) institutional culture or ethos; ii) curriculum content and centredness; iii) equal opportunity, access and redress; and ... iv) governance' (Makgoba 1997, 209). It is obvious, says Makgoba, that

transformation of universities in South Africa involves major academic, intellectual and philosophical arguments about who and whose knowledge to teach, learn and research. The transformation is about Africanism versus Europeanism on the African continent. (Makgoba 1997, 173)

I think that Makgoba is right about the factors underpinning and the parameters in the process of transformation. Yet, I want to suggest that if anything qualifies as 'knowledge', then the question concerning 'whose knowledge' (African? European?) is simply misguided. Second, transformation of universities in South Africa is arguably as little about 'Africanism' as it is about 'Europeanism'. It is, rather, about democratisation and enabling conditions for scholarly pursuits.

\section{Knowledge}

'Epistemologically,' Jerome Schiele argues, the Afrocentric perspective places considerable emphasis on an affective way of obtaining knowledge .... That is, knowing (i.e., understanding events and reality) 
through emotion or feeling is considered valid and critical from an Afrocentric standpoint. .... The focus on affect in Afrocentricity does not prevent recognition and use of rationality. Rather, affect, as a means of knowing, is viewed as offsetting the use of rationality. (Schiele 1994, 153).

With regard to higher education, says Schiele, 'a major role or expectation of the teacher would be to emphasize and foster a subjective as well as a cognitive experience of knowledge among students' (Schiele 1994, 156). Education clearly ought to engage both the intellect of the student (her capacity for effective thinking and for understanding) and her feelings. It is neither desirable that students be guided solely by their feelings or emotions nor that they be guided exclusively by their intellect. Feelings on their own are not a trustworthy guide because they change, often quickly and radically. Yet, to expect students to rely on their intellects alone would be to treat them as intellectual robots. The idea of massproducing intellectual robots acting solely on principle or on the basis of costbenefit analyses, and who dismiss the rational significance of feeling and caring, is not an attractive one. Yet, one might ask, what does any of this have to do with Afrocentrism, as opposed to basic, universal pedagogic considerations?

According to Makgoba,

The issue of pursuit of knowledge for its own sake and the so-called standards have ... become contentious factors around the African university. ... The pursuit of knowledge for its own sake has been one of the cornerstones of university education; but, is there such a thing as knowledge for its own sake today? Knowledge is a human construction that by definition has a human purpose. Knowledge cannot be sterile or neutral in its conception, formulation and development. Humans are not generally renowned for their neutrality or sterility. The generation and development of knowledge is thus contextual in nature. (Makgoba 1997, 177).

That knowledge ascription and justification have a crucial contextual component is surely not in doubt (see Horsthemke 2004), but this does not mean that (the pursuit of) knowledge must be described and explained in consequentialist or constructivist terms. It might be the object of knowledge that is and continues to be the legitimate cornerstone of higher education.

'The global competition, the involvement of industry in universities, the social, economic and political pressures of modern society, have made the [pursuit of knowledge for its own sake] obsolete', says Makgoba. 'The pursuit of knowledge and the truth with a purpose and social responsibility is what universities are about' (Makgoba 1997, 181, 182). Surely setting up a commission like the Truth and Reconciliation Commission also involved a non-instrumental understanding of knowledge and truth (see Horsthemke 2004). If they had an exclusively instrumental function, then substituting them would be entirely permissible - 
say, with 'amnesia pills' -, as long as the desired end/effect/outcome was the same. With regard to the traditional roles that universities throughout the world have in society, Makgoba mentions

the preservation, the imparting and the generation of knowledge. ... It is important to recognise ... that the imparting of inappropriate or irrelevant education, even of the highest calibre, would ... lead to a poor and ineffective product. Thus university education has to be relevant not only to the people, but also to the culture and environment in which it is being imparted. (Makgoba 1997, 179).

Without doubt: the trick, of course, is to avoid an education (system) that is impoverished as a result of excessive concerns with 'people's culture' and 'userfriendliness'.

\section{Africanisation of higher education and Afrocentric education}

In tackling the 'issue that Africanising institutions in context and curriculum or staffing them by Africans lowers standards', Makgoba states that the

freedom of the African continent from colonial rule has one inherent dimension to it: the African must be free to do and choose as he deems fit. ... Africanisation challenges ... the superiority mentality of racism and the imitative philosophy that in the long term will lead to the perpetual albeit sophisticated enslavement of Africans into the future. (Makgoba 1997, 177).

This disparagement of 'the imitative philosophy' is ironic, coming from Makgoba, considering his recent diatribe in the Mail and Guardian on 'dethroned white men' and what they ought to do - namely, imitate the 'new masters' (Makgoba 2005, 23).

Makgoba continues, 'Africanisation seeks to provide a basis for originality and uniqueness that can contribute meaningfully to global knowledge and civilisation' (Makgoba 1997, 178). As an 'example of how the institution should "Africanise", he suggests bringing

traditional healers into the system. If our Western doctors were to interact more with traditional healers, we might learn a lot, and we might be able to teach them too. The point is that without the participation of these people, we'll never be able to institute the primary health care system we need. (Makgoba 1997, 194).

It is unclear whether this amounts to 'Africanisation'. It does mean acknowledging the variety, expanse and multitudinous facets of health care education and knowledge.

Distinguishing between 'physical' and 'psychological Africanisation', Makgoba claims that the former deals with numbers: 'As the majority of our population is African, over time most societal activity will fall under their care'. By contrast, the 
latter 'involves a paradigm shift in mind-set wherein the process is accepted as a vital element in the survival of South African society' (Makgoba 1997, 200). And: 'As education is one of the cornerstones of every successful society and tertiary education in particular its highest form[,] the Africanisation of South African tertiary institutions becomes essential', according to Makgoba.

Africanisation is the process or vehicle for defining, interpreting, promoting and transmitting African thought, philosophy, identity and culture. It encompasses an African mind-set or mind-set shift from the European to an African paradigm. (Makgoba 1997, 203).

What is 'the' European paradigm? What is 'an African paradigm' or 'mind-set'? Makgoba provides no clues but goes on to contend that ' $[\mathrm{t}]$ hrough Africanisation we affirm and identify oursel[ves] in the world community' (Makgoba 1997, 203). 'The challenges facing Africa are twofold', he maintains. 'The need for educating a manpower force that is vested in science, engineering and technology, education, management and the arts is critical' (Makgoba 1997, 204). Regarding the 'second challenge', Makgoba refers to

the incorporation into ... courses material of our indigenous culture as part of scholarly endeavour, eg. African traditional political systems, philosophies and codes of behaviour, literature, music and dance. A teacher who does not understand or respect the culture of his pupils cannot reach their minds; [whoever] is out of touch with the society he serves cannot serve that society well. (Makgoba 1997, 204).

Turning his attention to 'the major barriers to Africanisation', Makgoba mentions the 'politicisation of the word Africanisation, the strong concerted effort to marginalise African culture and the tendency to regard and treat people of African origin as inferiors' (Makgoba 1997, 206).

I want to point out several errors here. First, it is unclear whether an emphasis on 'Africanisation' is appropriate for facing 'the realities and challenges of the future'. It is clear, incidentally, that 'Africanisation' itself is already a highly political and politicised word or term. Second, marginalisation and treatment or regard as inferior of African people, their cultures and identities, are themselves causes of appeals to Africanisation, or at least have given rise to the need for such appeals - they are not 'barriers'. Third, a legitimate barrier to Africanisation is its limited plausibility as a concept, given for example the relativism it entails. If anything, it is the concept of Africanisation that has a (self-)marginalising effect. In addition, Makogoba's statement, 'Central to transforming higher education in South Africa is the elimination of the present racist, dominant, Eurocentric education and its total replacement by a new non-racial, equitable Afrocentric education' (Makgoba 1997, 209; emphasis added), may well be a contradiction in terms. 


\section{Diversity, internationalisation and global economic competition}

Quite plausibly, Makgoba points out that '[d]iversity in all its various forms is an imperative an integral part of education ...':

Unless we draw upon the diversity of ideas, experiences and perspectives inherent in our society, we cannot generate the intellectual and social vitality that is necessary in a rapidly technological and transforming world of the $21^{\text {st }}$ century. ... Equal opportunity, freedom from discrimination and plurality, the foundations of a university, if applied correctly, can only lead to diversity. (Makgoba 1997, 219).

He adds,

Our country has diverse cultures, backgrounds, languages and institutions. These institutions are essential to provide the educated peoples and the ideas so necessary in our society to understand and build unity out of our diversity. ... Diversity is the untapped variable of the transformation equation. (Makgoba 1997, 220, 221).

This is evident, one might respond, but does 'Afrocentric education' not contradict the imperative of diversity? Makgoba maintains, 'It is the duty of academics and scholars to internationalise, articulate, shape, develop and project the image, the values, the culture, the history and vision of the African people and their innovations through the eyes of Africans':

African people should develop, write, communicate and interpret their theories, philosophies, in their own ways rather [than allow these to be] construed from foreign culture and visions. (Makgoba 1997, 205).

\section{Moreover,}

global economic competition is high and unless we develop a competitive high technology economy we face economic ruin, stagnation and under-development, with dire consequences for the impoverished rural and urban communities. (Makgoba 1997, 179).

Precisely. But is 'Africanisation' compatible with 'internationalisation', with developing 'a competitive high technology economy'? I fail to understand how an Afrocentric orientation is supposed to cater for the demand, 'as we enter the era of globalisation, ... to rethink ourselves anew, and bring in new ideas if we are to be a significant part of the information age and an era of knowledge industries' (Ntuli 2000,66 ) or with the 'need to develop people and prepare young South Africans for the future and the tough world of global competition' (Makgoba 2003, 2). It appears to me that the sooner the increasingly artificial 'African'/'European' dichotomy is dropped from musings on transformation the better.

It might be argued, of course, that there are broad, inclusive notions of Africanism, Africanisation and Afrocentrism at work here that are not based on 
skin colour and/or race (see Makgoba 1997, 199). Yet, given the very essence of these concepts, the question will at some point arise: Who or what is (to be) included and who or what is (to be) excluded, and on what grounds? (Should all those be included who are willing to 'imitate' the new, African masters? See Makgoba 2005.) If the ideas in question are to be broadly inclusive, then the question might be asked as to what work they do that is not done by the ideas of multiculturalism, interculturalism or transculturalism. A legitimate response might be: 'preservation of (African) culture(s) and identity/identities'. Even if fixing culture or identity in such a way were possible (which is doubtful: if there is an essential feature that characterises both culture and identity, it must be that of fluctuation, impermanence, adaptability etc.), it is arguably not desirable. Preservation of culture or identity for the sake of preservation is also bound to perpetuate questionable 'values', hidebound attitudes and the like, by confusing stability and rigidity.Much as I am in sympathy with many of the demands, concerns and hopes expressed by Africanists, I think that (the idea of) 'an Afrocentric philosophical model' is fundamentally flawed. The frequently expressed view, that '[a] fundamental difference in the conception of human beings between the Afrocentric and Eurocentric philosophical models is that whereas there is considerable emphasis on harmony and collectivity within the Afrocentric perspective, considerable emphasis is placed on domination, conflict, and fragmentation within the Eurocentric perspective [which therefore] tends to engender an individualistic and materialistic orientation toward life' (Schiele 1994, 154), is a misconception. First, what is a 'Eurocentric perspective'? Second, I am unaware of any serious and representative view that emphasises 'domination, conflict, and fragmentation'. Third, Schiele's view is clearly contradicted by the 'occidental' (as opposed to 'Eurocentric') communitarian tradition. In addition, an individualistic orientation need not be 'selfish' or 'egoistic' (this is a further common misconception!), but is perfectly compatible with compassion and empathy, a concern with other individuals as individuals. In fact, it is what arguably makes compassion and empathy possible in the first place.

There are further problems. The assertion, 'Unlike the fragmented and restricted view of human beings found in the Eurocentric perspective, Afrocentricity offers a more holistic conception of human beings' (Schiele 1994, 154; emphasis mine), is clearly a contradiction in terms, unless 'holism' is interpreted as extending over all, and only, Africans. (Moreover, is holism a matter of degree?) An equally worrying suggestion concerns 'the conception of teacher/ student relationships [as] based on cooperation and harmony ... within an Afrocentric framework' (Schiele 1994, 155-156). I suggest that to reject Eurocentrism by embracing Afrocentrism is similar to responding to schoolground bullying with corporal punishment, or to murder with capital punishment. Motivational reasons do not amount to justification, in any of these cases. Finally, 
targeting 'Eurocentrism' is akin to setting up a straw man for easy demolition. It is a wildly implausible orientation that few, if any, self-respecting theorists still subscribe to.

To some extent, the historical revisionism in Afrocentrism constitutes a welcome challenge to established historical understandings. Yet, a disconcerting amount of Afrocentric historiography can at best be considered mythology and at worst fabrication. The inaccuracies propounded by Afrocentrism are only part of what makes it problematic as an educational movement. The major problem with Afrocentric education is discrimination, in its cultivation of a reverse racial ideology and sense of racial superiority (see Gutmann 1996, 158).

\section{AFROSCEPTICISM}

On the other end of the spectrum, doubts about the idea of 'Africanising' universities frequently give rise to a kind of 'Afroscepticism'. Afrosceptics express doubts about the Africanisation of higher education, on the grounds that it involves reverse discrimination, self-marginalisation, the lowering of standards, and is ultimately incompatible with a commitment to multiculturalism and diversity, as well as unlikely to prepare students for global economic competition. Moreover, Afrosceptics have grave misgivings about the curtailment of university autonomy (as required in Makgoba 1997, 216-218, and Moulder 1995, 8). The argument is that such curtailment is likely to increase top-down decision-making and thereby also to impact on academic freedom.

An Afrosceptic might also point to several highly questionable pronouncements made by leading intellects and defenders of Africanisation. She would refer to Pitika Ntuli, on the validity and desirability of the amaqhikiza system (a type of mentorship programme among older and younger girls 'to ensure sexual abstinence' until the latter are 'ready to take full control of their affairs') and of ukuhlolwa kwezintombi or 'virginity testing' in girls (that 'seeks to achieve the goal of purity in the context of the spread of HIV/AIDS'; Ntuli 2002, 61, 62), and to Ramose, on the compatibility of ubuntu and polygamy: 'That marriage should not of necessity be monogamous is one of the ancient practices of ubuntu philosophy' (Ramose 2002, 329). Given the reality of (especially South) African polygamy, this declaration is tantamount to 'ubuntu for men'. The critic would argue that the fact that some of its 'leading lights' can err so conspicuously, by embodying the bastion of androcentric, sexist tradition, does not bode well for the reputation of the movement, at any level of education.

This critical or sceptical perspective encompasses responses to three, fairly broad questions, responses that have clear implications also for higher education:

(1) Given Africa's misery, what is its extent and what are Africa's prospects?

(2)Who or what is to blame for Africa's woes?

(3) Why is Africa to blame, if only in part? 
Bartholomäus Grill, Africa correspondent for the German weekly newspaper Die Zeit, demonstrates in his book (Alas, Africa. Reports from inside a continent) the devastating consequences of the slave trade and colonialism. Yet, he also takes on those postcolonial conspiracy theories that place the blame for these miseries squarely on the first world. The main responsibility resides with Africans themselves, with despotic leaders and the plundering elites. Grill's provocative thesis states that the modernisation of Africa has failed because it has been rejected by Africans. The old Africa has died, the new Africa has not yet been born. Grill depicts a continent torn between tradition and modernity. The region south of the Sahara is facing changes as radical as those facing Europe at the time of the 30year war. States are falling apart, civil wars keep flaring up, millions of homeless people roam about, reduced to a nomadic existence, as AIDS wipes out entire communities. It could take decades before some stability or order begins to manifest itself between Khartoum and Khayelitsha. Grill is not essentially an 'Afrosceptic'. Some of the excerpts that follow are either views that Grill examines critically or are Grill's own arguments that also happen to characterise Afroscepticism.

\section{Given Africa's misery, what is its extent and what are Africa's prospects?}

American taxes must no longer be pumped into 'rat-holes', according to (American) Republican senator Jesse Helms - a verdict that typifies what might be called 'racist Afroscepticism'. Africa is written off: geostrategically insignificant, economically marginal, politically a hopeless case (Grill 2003, 225). Other, more nuanced (non-racist) considerations - which indicate that higher education, too, is under siege - include Africa's marginal share in the world's economy (Hofmeier and Mehler 2004, 157), lack of global competitiveness and development opportunities, disease, reduced average life expectancy, poverty and scarcity, as well as the consideration that modernisation has failed on the continent. The 'black' continent constitutes the taillight of the world's economy; its share in global trade has dropped to 1 per cent, 40 per cent of its gross social product being allotted to South Africa. The majority of sub-Saharan countries are worse off today than towards the end of the colonial era. Half of the 650 million Africans live in extreme poverty (Hofmeier and Mehler 2004, 21); every third child is malnourished. Food production cannot keep pace with population growth. Close to 30 million people are infected with HIV or have contracted AIDS (Hofmeier and Mehler 2004, 133). The average life expectancy has shrunk to 48 years (Hofmeier and Mehler 2004, 21). Pessimists prophesise that the next generation will be even poorer, even more diseased and badly educated, and will stand even less of a chance in the global competition. 


\section{Who or what is to blame for Africa's woes?}

There are two schools of thought with regard to the question of blame. The first, which is frequently if not essentially informed by Afrocentrist perceptions, places the blame for these miseries equally on colonialism, and its consequences, and on the indifferent, arrogant, racist first world. The second, characterising Afrosceptics, blames Africa herself, despotic rulers, the corrupt elites, traditional leaders, even ordinary people, and also naïve development aid.

'They bewail the loss of their paradisiacal past. Psychologically, they live in the middle ages. They accomplish nothing to overcome their plight. They are cowardly, lazy and lachrymose.' The person thus judging Africans is an African woman, Axelle Kabou (Kabou 1991). After leaving her job as coordinator of development projects and advisor to several African presidents, she wrote a polemic pamphlet in which she claimed that Africa is on the edge of an abyss, that the continent's performance is the poorest of all, that nothing has been accomplished in the decades following independence. Kabou's reading in Dakar from her work, Et si l'Afrique refusait le développement? (And if Africa refused development?), kindled a blaze of anger. She was called a traitor, a woman who had sold her soul in Paris and who was no longer a daughter of Africa.Kabou is breaking a taboo. She blames not only power-crazy heads of state and the corrupt elites for the plight of the continent, but also ordinary people, each and every individual. Africans still believe that the world owes them salvation of the continent, as belated compensation for past injustices, their victim- and beggar mentality being strengthened by the sentimental humanitarianism of naïve white aid workers. Africans should look in the mirror, in order to realise their own part in this misery. Yet, they refuse to do this. It is the others who are to blame, foreign companies, the unjust global system of trade, the World Bank, the debt and poverty trap - not to mention the inherited burdens of colonialism. The black elites and the white helpers are united in their dogma that there exists a century-old plot by the white man against the black man, while they refuse to contemplate the more complex causes of this perpetual crisis.

Many consider Kabou's claim, that 'Africa-this-wonderful-continent-that-wasin-perfect-harmony-before-the-invasion-of-the-colonisers' is an anti-colonialist myth and has nothing to do with reality, downright blasphemous. Certainly, her pamphlet is not without stereotyping, of 'the Africans' as such. She tends to neglect the external factors of this chronic crisis, like the deprivation syndrome that white rule has left behind in the collective psyche. She also forgets that Africa lacks the springboard for the huge leap from agrarian society to industrial society. Modernisation was forced onto a continent that was unable to support it, sociostructurally and culturally, while the existing entrepreneurship and infrastructure were systematically undermined and destroyed by the colonial masters (Grill 2003, 115). There is no room for such historical subtleties in Kabou's general account. Nonetheless, no serious debate about the problems facing Africa can afford to 
ignore her fundamental thesis. She refers not only to the failed modernisation of postcolonial Africa but to modernisation that was refused, Africans being 'the only people on earth who still think that others must take care of their development' (Kabou 1991).

Kabou does not simply intend to condemn her African contemporaries. She wants to rouse them, into shaking off their 'unbearable mediocrity'. She demands self-criticism, a virtue that one does not encounter frequently south of the Sahara: Africans tend to have an allergic reaction towards criticism from others. Every critical comment or observation is perceived as neo-colonial carping or even racist arrogance - not only in South Africa, where black people have every reason to distrust their fellow white South Africans.

In Africa, those who desire to rise above the equality of poverty are drawn back into it - through the unwritten law of sharing that used to serve to guarantee the traditional community's survival. Yet, in modern society it prevents the accumulation of savings, the evolution of homo economicus, the birth of a dynamic middle class. This will continue for as long as the mentality of Africans does not change. And their mentality is not likely to change, as long as the elites drag their feet with regard to, and refuse, real reforms pertaining to the economic and political basis (Grill 2003, 141).

\section{Why is Africa to blame, if only in part?}

A multitude of factors are cited in response to this question: Africans' lack of initiative and laziness; the fact that they are still 'living in the past'; their victim and beggar mentality and incapability of self-criticism; superstition, barbarism, cruelty, violence and sexism; reverse racism ('positive discrimination'), racist nationalism, or xenophobia, and non-tolerance of dissent; corruption; Africa's rejection of 'western' democracy; and finally her refusal of modernisation and development. Grill admits that

Africa has taught the chronicler to be cautious. The history of rampant corruption in the back of his mind, he is careful not to rule out the possibility that history will not repeat itself elsewhere. Nonetheless, he keeps asking himself the same questions again and again: Why have honourable men who once led liberation struggles, who overcame colonial regimes and took up their position full of idealism, degenerated to lousy despots? (Grill 2003, 165).

Throughout Africa, educational work also faces a tough stand against the bastion of tradition. Like polygamy, the custom of widow inheritance is widespread, as is the phenomenon of 'dry sex' that is practiced in many population groups. The latter requires women to 'dry' their vagina either with chemicals or with a mixture of bark, herbs, paper or soil and baboon urine. Although it is burdensome, painful and degrading to most women, men value this practice, not only because it allegedly allows them a more intense experience of their masculinity during sexual 
intercourse: there is also a tendency to view a 'moist' vagina as a sign of 'sluttishness' and promiscuity. When these practices are questioned, one obtains disturbing answers: these are time-honoured traditions, rights of custom that have always existed, and what has always existed is useful and normal. Normal - like genital mutilation of girls, or like the putting out of children's eyes, a custom that is still in use today in certain Mozambican fishing villages. The eyeballs are fastened to fishing nets so that these can 'detect' their prey. 'You Europeans will never be able to understand this, the keepers of tradition tell us', Grill reports:

[The truth is that w]e have no desire to understand these barbaric rituals.In Africa, women are seldom asked. As a rule they have neither rights nor property. Men preside over economic, social and sexual matters. After all, they have paid lobola, the bridal fee, and adhere to the motto of Nigerian pop legend Fela Kuti: 'Women exist to make men happy.' (Grill 2003, 266; on the inherent sexism in many African cultures, see Oduyoye 1979 and Presbey 2002).

Still, says Grill, nothing is like it used to be, and nobody knows what will happen. South Africa, too, is a country in transition, having not yet discovered itself and its place in Africa (Grill 2003, 282). The old South Africa no longer exists. Now whites stand by and watch as blacks occupy the symbols of 'their' state. In addition, they get to experience the kind of marginalisation they themselves have institutionalised. There are those implacable radicals among blacks who even deny the former's right to be here. Who is African? Racist nationalism returns in a black cloak, according to Afrosceptics, and the new order gives birth to a new type of loser: the white labourer, specialist, employee who sees his existence threatened by affirmative action. The quota system for disadvantaged blacks is highly contentious because it does not exclude the possibility of injustices and often catapults those with the right skin colour into positions of power for which they are insufficiently qualified or not qualified at all. Mamphela Ramphele has little sympathy for the complaints of those who have benefited from the longest and most effective promotion system of modern history. Apartheid had in turn guaranteed every white person work, by means of job reservation, even when their abilities were rather limited, to put it mildly. Nevertheless, there is no denying that a government intent on overcoming racial arithmetic is busy retracing the dividing lines of skin colour, in terms of 'positive discrimination' (Grill 2003, 321, 322). The net result of this is the emigration of competent forces so vital for the country, the so-called 'brain drain'.

Furthermore, violence pervades South African society like a paralysing poison. When Grill asked Thabo Mbeki in an interview in 1998 what worried him most, he answered without hesitation: 'The lack of moral values'. This goes for every single population group, and especially for the age group that causes every society a headache: young men aged between and 15 and 30 (Grill 2003, 307). Who is African? Immigrants are derogatorily called kwerekwere, because of their 
unintelligible languages. They are insulted, persecuted, sometimes even killed the well-known excesses of xenophobia. Yet, this time they emanate from Africans - against Africans. Nonetheless, Afrosceptics maintain, the government behaves as if such problems occur only in affluent societies. On the whole it is somewhat allergic to criticism, especially if it comes from whites. Those who condemn its disastrous AIDS policy or who pose the uncomfortable question whether South Africa can really afford purchasing weapons, acquisition of which runs into millions, are accused of lack of loyalty, of a know-all and patronising manner. Dissent is generally treated with suspicion of racism, and 'racist' is used as a tried and tested gag to throttle such dissent (Grill 2003, 323).

\section{AFROREALISM}

The net result of the debate between Afrocentrism and Afroscepticism has been a kind of dialogical impasse between these two diametrically opposed positions, with both sides accusing one another of racial hegemonism (Ani 1994, 3; Murobe 2002, 581). There are valuable points and insights that characterise these different views and that need to be taken into account in order to arrive at a balanced perspective regarding African higher education in the twenty first century. Ultimately, neither Afrocentrism nor Afroscepticism provide a compelling framework for change or transformation of tertiary education, not least because of the racist and/or essentialist overtones of the respective orientations. My own position, while rather critical of the Afrocentric project and of the idea of 'the' African university, stops short of a thoroughgoing scepticism. It is informed both by what might be called 'Afrorealism' and the cautious hope that higher education in Africa will flourish in the twenty first century, whether in spite or because of globalisation.

Many of the doubts expressed by Afrosceptics (pertaining to disease, poverty, corruption - which all add to the non-African world's lack of interest and concern) are valid. However, the general failure to make the transition to modernity and democracy must be understood against the background of the slave trade, colonisation and globalisation. The process that is today called globalisation was initiated by the mass deportations of slaves (Grill 2003, 74). The modern global system came to Africa in the shape of the slave trade and colonialism. These constitute a historical continuum that forms the basis for the economic dependence of the 'black' continent on Europe, the 'development of underdevelopment', for the integration of Africa into this global system has failed. Africa was not modernised, it was marginalised, as Congolese philosopher Valentin Mudimbe notes (Grill 2003, 98). The realisation is gradually dawning that the seeds for this failure were contained in development aid itself. The colonialism that takes has been replaced by one that gives, according to philosopher Alexandre Kojève. All 
schools of thought that characterised this donor colonialism had the common characteristic that they placed confidence in growth and industrialisation, and they all failed (Grill 2003, 117, 118).

\section{Prospects for Africa and her universities}

What, then, is 'Africa'? In a sense, Africa was invented as an object of conquest. Of course, the continent became properly 'African' as an object of liberation Africans gained their continental identity in their struggle against Europeans. Nevertheless, Africa as a homogeneous whole - as it is depicted in Europe (and by many Afrocentrists) - does not exist. For that matter, neither does 'Europe': this, too, is a misconception that characterises Afrocentrism and Afroscepticism alike.

Like 'the essence of Africa', or 'African culture and identity', the 'African university' is a myth. What African universities share, however, apart from their continental location, is that they are under threat from very similar directions: Africa's marginal share in the world's economy, lack of global competitiveness and development opportunities, disease and reduced average life expectancy of staff and students, lack of resources, mismanagement of funds, as well as the consideration that modernisation has failed on the continent, the two-pronged requirement of 'political correctness' and of deference to custom and tradition, not to mention top-down demands that universities relinquish whatever 'autonomy' they might still possess. What to do? It would certainly also help universities a great deal if the world's economic powers supported the New Partnership for Africa's Development (NEPAD), a programme for continental reconstruction modelled on the Marshall Plan that was inspired by Mbeki. The central idea is that Africans mobilise their self-help capacities and thus enable the political and economic course corrections that have been long overdue. The first world enforces financial cooperation, writes off Africa's suffocating debts and commits to a stepby-step abolition of all those trade structures that serve to marginalise the third world (Hofmeier and Mehler 2004, 215, 216).

'The power of forgiveness and the courage of reconciliation' - these are for Grill 'perhaps the most significant lessons we can learn from Africa' (Grill 2003, 19).

The mere fact that the [Truth and Reconciliation] Commission was welcomed by the overwhelming majority of the black victims and rejected by the predominantly white perpetrators speaks for this contentious experiment. The humiliated and tortured were able to testify coram publico as to what had been done to them. Catharsis, healing through speaking and hearing the truth: henceforth, no one would be able to deny the crimes of apartheid.

Grill speaks of the

unbelievable readiness for reconciliation among the overwhelming number of black, 
coloured and Indian victims. No threats, no acts of revenge, no vigilante justice, nothing. (Grill 2003, 315).

'One would despair at this continent,' he writes,

were it not for this incredible force of forgiveness. The South African Truth Commission managed to expose the crimes of apartheid and to establish a universal model for reconciliation. Nowhere else are the wounds as deep as in Africa, nowhere else do they heal as quickly. According to historian Ali Mazrui, Africans have a 'short memory of hate'. (Grill 2003, 360, 361).

Prospects? Apart from the desirability of a Truth and Reconciliation Commission for education, in particular (see Horsthemke 2004), everything appears to hinge on the eradication of poverty. The success of NEPAD arguably holds greater promise for the continent and, in particular, African universities than any talk of Africanisation or Afrocentric education. In fact, I would suggest, the imperatives of internationalisation and educating for diversity should incline us in a direction contrary to the latter. It is crucial, of course, to commit to an enabling, internationally competitive tertiary (as well as technical and practical) education system. Finally, the 'taker' mentality must not be allowed to infiltrate higher education, but university education must feed back into the community - in terms of both interrogating questionable customs and traditions and educating against a victim- and/or beggar mentality.

\section{REFERENCES}

Ani, M. 1994. Yurugu: An African-centered critique of European cultural thought and behaviour. Trenton: Africa World Press.

Asante, M.K. 1980. Afrocentricity: The theory of social change. Buffalo, NY: Amulefi. . 1987. The Afrocentric idea. Philadelphia: Temple University Press.

Grill, B. 2003. Ach, Afrika. Berichte aus dem Inneren eines Kontinents. Berlin: Siedler.

Gutmann, A. 1996. Challenges of multiculturalism in democratic education. In Public education in a multicultural society, ed. R. K. Fullinwider, 156-179. Cambridge: Cambridge University Press.

Hofmeier, R. and A. Mehler. (Eds). 2004. Kleines Afrika-Lexikon: Politik-Wirtschaft-Kultur. Munich: C.H. Beck.

Horsthemke, K. 2004. 'Indigenous knowledge', truth and reconciliation in South African higher education. South African Journal of Higher Education 18 (3): 65-81.

Kabou, A. 1991. Et si l'Afrique refusait le développement? Paris: L'Harmattan.

Makgoba, M. W. 1997. Mokoko: The Makgoba affair. A reflection on transformation. Florida: Vivlia.

2003. An African vision for mergers. Beyond Matric/Mail and Guardian May 2-8: 1-2. 2005. Wrath of dethroned white males. Comment and Analysis/Mail and Guardian March 22-31: 23.

Moulder, J. 1995. Universities and 'Africanisation'. South African Journal of Higher Education 9(1): 7-8. 
Murobe, M. F. 2002. Globalization and African Renaissance. In Philosophy from Africa. ed. P. H. Coetzee and A. P. J. Roux, 574-588. $2^{\text {nd }}$ edition. Cape Town: Oxford University Press Southern Africa.

Ntuli, P. P. 2002. Indigenous knowledge systems and the African Renaissance: Laying a foundation for the creation of counter-hegemonic discourses. In Indigenous knowledge and the integration of knowledge systems: Towards a philosophy of articulation, ed. C. Odora Hoppers, 53-66. Claremont: New Africa Books.

Oduyoye, A. 1979. The Asante women: Socialization through proverbs. African Notes 8.1: 511.

Pityana, B. 2004. If not now, then when? Beyond Matric/Mail and Guardian May 7-13: 1, 4. Presbey, G. M. 2002. Should woman love 'wisdom'? In Philosophy from Africa, ed. P. H. Coetzee and A.P.J. Roux, 361-372. $2^{\text {nd }}$ edition. Cape Town: Oxford University Press Southern Africa.

Ramose, M. B. 1998. Foreword. In Black perspective(s) on tertiary institutional transformation, ed. S. Seepe. Johannesburg: Vivlia.

. 2002. The ethics of ubuntu. In Philosophy from Africa, ed. P. H. Coetzee and A. P. J. Roux, 324-330. $2^{\text {nd }}$ edition. Cape Town: Oxford University Press Southern Africa.

Schiele, J. H. 1994. Afrocentricity: Implications for higher education. Journal of Black Studies 25 (2): 150-169.

Seepe, S. 2000. Africanization of knowledge: Exploring mathematical and scientific knowledge embedded in African cultural practices. In African voices in education, ed. P. Higgs, N. C. G. Vakalisa, T. V. Mda, N. T. Assie-Lumumba, 118-138. Lansdowne.

Van Sertima, I. 1999. The lost science of Africa: An overview. In African Renaissance - The new struggle, ed. M. W. Makgoba. Mafube Publishing.. 